\title{
PENGARUH PENDAPATAN ASLI DAERAH, DANA ALOKASI UMUM, DANA ALOKASI KHUSUS DAN DANA OTONOMI KHUSUS TERHADAP BELANJA MODAL DI PAPUA BARAT TAHUN 2014-2018
}

\author{
Theresia P. Wanma \\ Yundy Hafizrianda \\ hariman.andalan@gmail.com \\ Syaikhul Falah \\ sehufalah@gmail.com
}

\begin{abstract}
The purpose of this study was to examine and analyze the influence of PAD, DAU, DAK and DOK on Capital Expenditures in West Papua Province in 2014-2018. This study uses secondary data, namely the budget originating from PAD, DAU, DAK and DOK which are allocated for Capital Expenditures in 12 Regencies and 1 City in West Papua Province. The analytical tool used is Multiple Linear Regression with IBM SPSS 21 application.

The results of the study show that local revenue, general allocation funds and special allocation funds have no effect on capital expenditure, while the special autonomy fund has a positive and significant effect on capital expenditure. Furthermore, simultaneously PAD, DAU, DAK and DOK have no significant effect on Capital Expenditures.
\end{abstract}

Keywords: PAD, DAU, DAK, DOK and Capital Expenditures

\section{PENDAHULUAN}

Dalam upaya pelayanan disektor publik untuk menciptakan kenyamanan masyarakat, Pemerintah daerah perlu meningkatkan kemandirian daerah. Untuk mewujudkan kemandirian daerah tersebut, perlu diberikan alokasi belanja yang besar untuk peningkatan layanan public guna meningkatkan daya tarik investor dalam rangka membuka usaha di daerah Harianto \& Adi (2007). Pengeluaran anggaran dalam pencapaian pendapatan dalam laporan Anggaran Pendapatan dan Belanja Daerah (APBD) adalah definisi Belanja Modal dari PP 71 Tahun 2010. kebutuhan daerah akan sarana dan prasarana untuk kelancaran pelaksanaan tugas pemerintahan maupun untuk fasilitas public digunakan sebagai dasar penganggaran belanja modal . Maka dari itu, dalam upaya meningkatkan kualitas pelayanan public pemeritah daerah perlu mengubah komposisi belanjanya.

Belanja modal merupakan penggunaan dana yang nantinya dapat meningkatkan aset daerah dan dapat meningkatkan biaya pemeliharaan dan 
perawatan didalamnya Mardiasmo (2002). Dengan diadakannya belanja modal, dapat berdampak secara menyeluruh meliputi makro dan mikro untuk perekonomian nasional, terutamnya perekonomian daerah Halim (2014). Menurut Ayinde, Kuranga, \& Rukman (2015) pengunaan dana yang dilakukan oleh pemerintah pada kegiatan khusus yang dipergunakan memaksimalkan pelayanan dan fasilitas masyarakat dalam jangka panjang adalah Belanja Modal.

Motivasi penelitian ini yaitu adanya perbedaan dari beberapa hasil penelitian terdahulu. Dana alokasi umum berpengaruh positif dan signifikan terhadap belanja modal Harianto \& Adi, (2007). Lain hanInya dengan penelitian Verawaty \& Mela (2015) menyatakan pendapat yang berlawanan yaitu bahwa dana alokasi umum tidak berpengaruh positif terhadap belanja modal. Penelitian Arbie (2013); Askam (2008); Martini et al (2014) menyatakan bahwa dana alokasi khusus berpengaruh positif dan signifikan terhadap belanja modal, sedangkan dalam penelitian Verawaty \& Mela (2015) menyatakan hal yang sebaliknya. Menurut Mawarni \& Abdullah (2013) pendapatan asli daerah berpengaruh positif terhadap belanja modal, sedangkan Arbie (2013) dan Yovita (2011) menyatakan sabaliknya yaitu bahwa PAD tidak berpengaruh signifikan terhadap belanja modal.

Dari penjelasan di atas, menarik bagi penulis untuk meneliti Pengaruh Pendapatan Asli Daerah, Dana Alokasi Umum, Dana Alokasi Khusus dan Dana Otonomi Khusus Terhadap Belanja Modal di Provinsi Papua Barat Tahun $2014-2018$.

\section{LANDASAN TEORI}

Pengeluaran produktif dan non produktif dibedakan dengan Kajian empiris tentang pengeluaran pemerintah berdasarkan pada model pertumbuhan endogen . 
Pengeluaran dikatakan produktif apabila mencantumkan berbaga argumen dalam fungsi produksi privat dan juga sebaliknya. Ini menjelaskan bahwa pembelajaaan dikatakan produktif jika menghadirkan suatu efek langsung atas pertumbuhan ekonomi dan sebaliknya tidak produktif maka tidak memiliki efek secara langsung $\mathrm{R}$. S. Barro \& Martin (1995). Isu tentang materi pengeluaran yang digolongkan produktif atau tidak produktif dapat dibantah.

Pengaruh pengeluaran pemerintah terhadap pertumbuhan ekonomi mempunyai Bukti empiris berbeda-beda, berdasarkan studi cross-section yang kerap terjadi di berbagai negara-negara berkembang dan maju. Kesimpulan utama dari beberapa studi, bahwa pengeluaraan konsumsi pemerintah memiliki sudut dampak negative Barro, (1991) dalam Easterly \& Rebelo, (1993). Studi yang menggunakan satu sampel hanya Negara maju (OECD) didapatkan hasil yang sama. Sebagai contoh : Hanson dan Henrekson (1994) mejelaskan pengeluaran konsumsi pemerintah dapat menyebabkan keterlambatan pertumbuhan ekonomi tetapi pengeluaran pada pedidikan dapat berdampak positif terhadap pertumbuhan. Kneller (1998) mengungkapkan sesuatu yang positif berasal dari pengeluaran produktif, sedangkan dampak negative atas pertumbuhan pada Negara-negara OECD (1970-1995) dikarenakan pengeluaran yang tidak produktif .

Barro (1998) mengemukakan hasil analisis dari pengaruh pendidikan terhadap pertumbuhan ekonomi 100 negara selama tahun 1960-1995. Variabelvariabel ini antara lain : Government consumptiow / GDP, years of schooling (as proxy of human capital), Life expectarcy, Inflation rate, Rule of law Index, democrazy Index, Fertility Rate, Investment / GDP, Growth rate of Terms of Trade. Sedangkan pertumbuhan GDP perkapita merupakan variable pengikat dalam analisa. Dengan memakai model analisis regresi linier berganda hasil penelitian 
tersebut memberikan kesimpulan adanya pengaruh yang cukup signifikan antara pendidikan dan pertumbuhan ekonomi. Variabel human capital memiliki peranan lebih besar terhadap pertumbuhan ekonomi dari pada variabel physical capital apabila dilihat secara lebih detail.

\section{Pendapatan Asli Daerah (PAD)}

Pendapatan Asli Daerah (PAD) adalah salah satu sumber pendapatan daerah yang termasuk dalam salah satu faktor yang mempengaruhi Belanja Modal. Pendapatan Asli Daerah yang merupakan pendapatan asli dari daerah yang dapat digali dan digunakan sendiri sesuai dengan potensinya masing-masing. Halim (2008) menerangkan bahwa semua penerimaan daerah yang berasal dari sumber ekonomi asli daerah disebut PAD. Sementara menurut Darise (2008), Pendapatan Asli Daerah adalah pendapatan yang didapatkan dari daerah yang diterapkan pemungutannya berdasarkan peraturan daerah. Dari kedua pengertian tersebut dapat disimpulkan bahwa yang dimaksud dengan Pendapatan Asli Daerah (PAD) adalah salah satu sumber yang menjadi pendapatan yang diterima daerah yang berasal potensi daerahnya masing-masing yang dapat digali dan digunakan secara mandiri oleh daerah.

\section{Dana Alokasi Umum (DAU)}

Bagian dari Dana Perimbangan serta menjadi sumber pendapatan dan menjadi salah satu faktor yang mempengaruhi besarnya pengaloksian Belanja Modal suatu daerah adalah Dana Alokasi Umum (DAU). Dana tersebut juga merupakan dana transfer dari pemerintah pusat kepada pemerintah daerah yang penggunaannya sepenuhnya diperuntukkan kepada daerah. Penjelasan pada UU Nomor 33 tahun 2004 dikatakan bahwa Dana Alokasi Umum merupakan dana yang bersumber dari Anggaran Pendapatan dan Belanja Negara yang 
dialokasikan dengan yang bertujuan untuk pemerataan kemampuan keuangan antar daerah dalam rangka pelaksanaan desentralisasi dan otonomi daerah.

Menurut Mardiasmo (2004: 144), Dana Alokasi Umum dimaksudkan untuk menjaga pemerataan dan perimbangan keuangan antara pusat dan daerah, sehingga dalam pembagian Dana Alokasi Umum perlu memperhatikan beberapa hal antara lain potensi daerah, kebutuhan pembiayaan untuk mendukung penyelenggaraan pemerintah di daerah dan ketersediaan APBN. Salah satu fungsi Dana Alokasi Umum yaitu sebagai faktor pemerataan fiskal. Faktor yang mempengaruhi banyak sedikitnya Dana Alokasi Umum untuk setiap daerah adalah celah fiskal (fiscal gap) dan potensi daerah (fiscal capacity). Daerah yang potensi fiskalnya besar tetapi kebutuhannya kecil akan memperoleh Dana Alokasi Umum yang relative kecil merupakan Prinsip alokasi Dana Alokasi Umum begitu juga sebaliknya.

\section{Dana Alokasi Khusus (DAK)}

Belanja Modal juga dipengaruhi oleh Dana Aloksi khusus. Dana Alokasi Khusus merupakan dana transfer dari pemerintah pemerintah pusat kepada pemerinah daerah selain Dana Alokasi Umum. Undang-undang Nomor 33 Tahun 2004 tentang perimbangan keuangan antara pemerintah pusat dan pemerintah daerah, Peraturan Pemerintah Nomor 55 Tahun 2005 tentang Dana Perimbangan dan Peraturan Menteri Keuangan Nomor 145/PMK. 07/2013 tentang pengalokasian Anggaran Transfer ke Daerah adalah Dasar hukum yang mengatur tentang Dana Alokasi Umum.

Mardiasmo (2004) menjelasakn bahwa Dana Alokasi Khusus ialah dana yang dialokasikan untuk membantu pembiayaan kebutuhan tertentu, yaitu merupakan program nasional atau program kegiatan yang tidak terdapat di daerah lain. Dari 
beberapa pengertian mengenai Dana Aloksi Khusus tersebut maka dikatakan bahwa yang di maksud dengan Dana Alokasi Khusus adalah dana transfer dari pemerintah pusat kepada pemerintah daerah yang bersumber dari APBN yang dialksikan kepada daerah tertentu untuk mendanai kegiatan khuus yang merupakan kewenangan daerah dalam hal penyedianan sarana dan prasaran daerah (fasilitas fisik).

\section{Dana Otonomi Khusus (DOK)}

Pemanfaatan DOK provinsi Papua serta Provinsi Papua Barat di Prioritaskan untuk pendananan pendidikan dan kesehataan, Infrastruktur dan ekonomi. dalam (APBN, 2018), Provinsi Papua dan Papua Barat diberikan dana otsus senilai Rp 8 trilyun. Kedua_provinsi ini juga mendapat dana tambahan infrastruktur senilai $\operatorname{Rp} 4$ Trilyun guna percepatan pembangunan infrastruktur. Sedangkan hubungan antara belanja modal terdapat dana otsus di sesuaikan dengan anggaran dana otsus di kirim dari pusat ke daerah dan untuk mendanai kebutuhan daerah berdasarkan fungsi pendidikan, kesehatan, ekonomi dan infrastruktur guna mempercepat pembangunan di Provinsi Papua dan Papua Barat (Yusharto, 2018).

\section{Belanja Modal}

Belanja Modal adalah Penganggaran untuk memperoleh Aset tetap dan aset lainnya yang memberi manfaat lebih dari satu periode akuntansi Halim (2008: 101). Pengertian tersebut sejalan dengan definisi Belanja Modal menurut UndangUndang No. 71 Tahun 2010 tentang Standar Akuntansi Pemerintahan. Menurut Darise (2008: 141), pengeluaran dalam rangka pembelian, pengadaan atau pembangunan aset tetap berwujud yang mempunyai nilai manfaat dalam periode akuntansi untuk digunakan dalam kegiatan pemerintahan, seperti dalam bentuk tanah, peralatan mesin, gedung dan bangunan, jalan, irigasi dan 
jaringan, dan aset tetap lainnya adalah Belanja Modal. Sementara menurut Mardiasmo (2004: 187), Belanja Modal adalah kelompok belanja langsung yang digunakan untuk membiayai kegiatan investasi (menambah aset).

Belanja Modal tidak hanya pengeluaran anggaran untuk pembelian aset atau inventaris, tetapi juga pengeluaran yang dilaksanakan oleh pemerintah daerah untuk mendanai pemeliharaan yang tujuannya menambah dan mempertahankan masa manfaaat aset, serta menambah kualitas dan kapasitas aset. Buletin Teknis Sistem Akuntansi Pemerintah Nomor 4 tentang Penyajian dan Pengungkapan Belanja Pemerintah mengungkapkan bahwa Belanja Modal adalah pengeluaran anggaran untuk perolehan aset tetap dan aset lainnya yang memberi manfaat lebih dari satu periode akuntansi. Aset tetap dan aset lainnya yang dimaksudkan adalah yang mempunyai karakteristik berwujud dan meningkatkan aset pemerintahan.

Belanja Modal dapat diartikan sebagai suatu bentuk kegiatan pengelolaan keuangan daerah yang perlu dikelola secara tertib, taat pada aturan, efektif, efisien, ekonomis transparan, dan bertanggung jawab dengan melihat asas kepatuhan dan keadilan, dan memberikan nilai manfaat untuk masyarakat. Ukuran kesuksesan dari penggunaan Belanja Modal sendiri yakni tepat sasaran, tepat harga, tepat waktu, tepat mutu dan tepat jumlah Halim, (2014: 229).

Terdapat beberapa cara untuk memperoleh aset tetap, antara lain dengan menukarkan dengan aset tetap lainnya, membeli dan membangun sendiri.

Berdasarkan Undang-Undang Nomor 32 Tahun 2004, pemerintah daerah mempunyai sumber-sumber pendapatan daerah berupa Pendapatan Asli Daerah (PAD) yang akan berpengaruh terhadap Belanja Modal.

Semakin tinggi Pendapatan Asli Daerah biasanya akan diikuti dengan meningkatnya Belanja Modal, kemudian menyesuaikan dengan kondisi pada saat 
tahun anggaran. Begitu pula dengan Dana Perimbangan dari pemerintah pusat berupa Dana Alokasi Umum, Dana Alokasi Khusus dan Dana Bagi Hasil.

Dengan diberikannya Dana Perimbangan dari pemerintah pusat diharapkan pemerintah daerah mampu meningkatkan jumlah persentase Belanja Modal daerahnya. Menurut Bambang Prakosa (2004), pengeluaran pemerintah daerah akan disesuaikan dengan perkembangan dalam penerimaan daerah atau perubahan pendapatan terjadi sebelum perubahan pengeluaran. Secara konseptual pendapatan atau pemasukan akan berpengaruh terhadap belanja atau pengeluaran. Dari pernyataan tersebut maka dapat dikatakan bahwa sumber-sumber pendapatan daerah dapat mempengaruhi alokasi Belanja Modal oleh pemerintah daerah.

\section{Hipotesis Penelitian}

Berdasarkan kerangka pemikiran serta tinjauan pustaka yang dijelaskan diatas maka hipotesis dari penelitian ini adalah :

H1 = Diduga PAD,DAU, DAK dan DOK berpengaruh negatif dan signifikan terhadap Belanja Modal di Papua Barat 2014-2018

H2 = Diduga PAD, DAU, DAK dan DOK berpengaruh positif dan signifikan terhadap Belanja Modal di Papua Barat 2014-2018

\section{METODOLOGI PENELITIAN}

\section{Lokasi Penelitian}

Lokasi penelitian di Manokwari pada kantor badan pengelolaan keuangan dan asset daerah (BPKAD) Provinsi Papua Barat dengan melihat anggaran yang bersumber dari PAD, DAU, DAK dan DOK yang di alokasikan untuk belanja modal di 12 kabupaten 1 kota Provinsi Papua Barat. 


\section{Metode Pengambilan Data}

Pada penelitian ini metode pengumpulan data yang digunakan adalah metode dokumentasi. Metode ini digunakan untuk memperoleh data mengenai data PAD, DAU, DAK, DOK dan belanja modal di pemerintahan Provinsi Papua Barat tahun 2014-2018 dimana data yang digunakan adalah Laporan realisasi APBD yang telah diterbitkan oleh Dirjen Perimbangan Keuangan Pusat, 2019.

\section{Jenis Penelitian}

Jenis penelitian ini adalah penelitian kuantitatif, penelitian kuantitatif merupakan jenis penelitian yang analisis datanya menggunakan angka-angka dan diolah menggunakan metode statistik Arbie, (2013). Sedangkan variabel penelitian terdiri dari variabel terikat dan variabel bebas. Variabel terikat belanja modal dan variabel bebas pendapatan asli daerah (PAD), dana alokasi umum (DAU), dana alokasi khusus (DAK) dan dan otonomi khusus (DOK) pada 12 kabupaten 1 kota di Provinsi Papua Barat.

\section{Definisi Operasional Variabel}

Belanja modal ialah belanja langsung yang diberikan oleh pemerintah provinsi Papua Barat pada 12 kabupaten 1 kota, untuk membiayai kegiatan investasi. Indikator variabel belanja modal antara lain : Belanja Tanah, Belanja Peralatan dan Mesin, Belanja Gedung dan Bangunan, Belanja Jalan, Irigasi dan Jaringan, Belanja Aset Lainnya (Yovita 2011).Pengukuran variable belanja modal ini diukur dengan skala rasio. Belanja modal dapat diukur dengan perhitungan berikut : 
Belanja Modal $=$ Belanja Tanah + Belanja Peralatan dan Mesin + Belanja Gedung dan Bangunan + Belanja Jalan, Irigasi dan Jaringan + Belanja Aset Lainnya.

1. Pengalokasian Belanja Modal adalah bentuk pengeluaran pemerintah dalam bentuk belanja daerah terhadap barang-barang publik yang bersifat modal yang diukur dalam nilai satuan rupiah per/tahun.

2. Pendapatan Asli Daerah bentuk penerimaan daerah yang bersumber dari Pajak Daerah, Retribusi daerah, Penerimaan perusahaan milik Daerah dan lainlain PAD yang sah yang diukur dalam nilai satuan rupiah per/tahun

3. Dana Alokasi Umum bentuk Transfer Pemerintah Pusat berupa Dana Perimbangan yang bersifat umum yang diukur dalam nilai satuan rupiah per/tahun

4. Dana Alokasi Khusus Transfer Pemerintah Pusat berupa Dana Perimbangan yang bersifat khusus yang diukur dalam nilai satuan rupiah per/tahun

5. Dana Otsus Khusus Transfer Pemerintah Pusat ke Daerah Provinsi Papua dan Papua Barat yang diukur dengan nilai satuan rupiah Per/tahun.

\section{Pendapatan Asli Daerah}

PAD merupakan sumber keuangan pemerintah provinsi se-Indonesia dari tahun 2012 yang ambil dari dalam wilayah daerah dan terdiri dari hasil pajak daerah, retribusi daerah, hasil pengelolaan kekayaan daerah yang dipisahkan, dan lain-lain pendapatan daerah yang sah. Pengukuran variabel PAD ini diukur dengan skala rasio. PAD dapat diukur dengan perhitungan : 
$\mathrm{PAD}=$ Total pajak daerah + total retribusi daerah + total hasil pengelolaan kekayaan daerah yang dipisahkan + lain - lain pendapatan daerah yang sah.

\section{Dana Alokasi Umum}

DAU merupakan dana yang berasal dari APBN yang dialokasikan dengan tujuan pemerataan kemampuan keuangan antar daerah untuk membiayai kebutuhan pengeluaran dalam rangka pelaksanaan desentralisasi. Indikator DAU adalah sebagai berikut :

1. Dari indeks kebutuhan daerah, terdiri dari : indeks penduduk atau pengeluaran atau belanja daerah rata-rata, indeks luas daerah, indeks kemiskinan relative, indeks harga bangunan.

2. Dari penerimaan daerah, terdiri dari : indeks industri, penerimaan daerah, indeks sumber daya manusi, indeks sumber daya alam (SDA), (SDM) Yovita (2011).

Variabel DAU ini diukur dengan menggunakan skala rasio. DAU dapat ditentukan dengan perhitungan :

DAU Kabupaten $/$ kota $=90 \%$ x 25\% x PDN (Pendapatan Dalam Negeri) $\mathrm{x}$ Bobot DAU.

\section{Dana Alokasi Khusus (DAK)}

DAK merupakan dana yang bersumber dari APBN yang diberikan tidak kepada semua daerah dengan sasaran untuk membantu mendanai kegiatan khusus yang juga merupakan urusan daerah dan selaras dengan prioritas nasional.

\section{Dana Otonomi Khusus}


Pembagian alokasi dana antara satu provinsi dengan provinsi yang lain berbeda-beda. Untuk provinsi Papua, sesuai dengan amanat UUD No. 21 Tahun 2001 tentang otsus bagi Provinsi Papua. Jumlahnya 70\% dialokasikan untuk provinsi Papua dan 30\% untuk Provinsi Papua Barat. Kewenangan pembagian alokasi seluruhnya diberikan kepada Pemerintah Daerah tujuannya memperkuat asas densentralisasi yang diatur dalam peraturan daerah khusus (PERDASUS), pemanfaatan dana otsus provinsi Papua serta Provinsi Papua di Prioritaskan untuk pendananan pendidikan dan kesehataan, Infrastruktur dan ekonomi.

Transfer Pusat DOK = PAPUA Rp 8 Triliun per/thn + PAPUA BARAT Rp 4 Triliun

\section{HASIL PENELITIAN DAN PEMBAHASAN}

\section{Hasil Penelitian}

\section{Hasil Deskriptif}

dalam penelitian ini Variabel independen adalah DAU, PAD, DAK dan DOK sedangkan belanja modal pada 12 kabupaten 1 kota di Provinsi Papua adalah variable dependen jika dilihat berdasarkan per-kabupaten/kota yang di Provinsi Papua Barat periode 2014-2018 yang sudah dihitungkan total akhir per/kabupaten kota sehingga sempel penelitian atau N 13. Dibawah ini disajikan hasil dari uji statistic deskriptif.

Tabel 4.14

Statistik Deskriptif Dalam Jutaan Rupiah Descriptive Statistics

\begin{tabular}{|c|c|c|c|}
\hline Variabel & Mean & Std. Devition & $\mathbf{N}$ \\
\hline BM Papua Barat_Y & $1,61 \mathrm{E}^{12}$ & $8,350 \mathrm{E}^{11}$ & 13 \\
\hline PAD_X1 & $2,03 \mathrm{E}^{11}$ & $1,993 \mathrm{E}^{11}$ & 13 \\
\hline
\end{tabular}




\begin{tabular}{|c|c|c|c|}
\hline DAU_X2 & $2,20 \mathrm{E}^{12}$ & $6,217 \mathrm{E}^{11}$ & 13 \\
\hline DAK_X3 & $7,48 \mathrm{E}^{11}$ & $2,024 \mathrm{E}^{11}$ & 13 \\
\hline DOK_X4 & $8,37 \mathrm{E}^{11}$ & $2,959 \mathrm{E}^{11}$ & 13 \\
\hline
\end{tabular}

Sumber: Hasil Output IBM SPSS 21, 2019

Berdasarkan hasil analisa statistik deskriptif di atas, dapat diperoleh hasil untuk belanja modal di 12 kabupaten 1 kota dengan rata-rata sebesar Rp 1.600.0000.000 dan standar deviasi sebesar Rp 8.350.000.000, PAD dengan rata-rata sebesar $\operatorname{Rp} 2.030 .000 .000$ dan besaran deviasi sekitar $\mathrm{Rp}$ 1,993.000.000. DAU dengan rata-rata sebesar Rp 2.200.000.000.000 dan statndar deviasi sebesar Rp 6.217.000.000. DAK dengan rata-rata sebesar Rp 7.480.000.000.000 dan standar deviasi sebesar Rp 2.024.000.0000 dan selanjuntnya adalah DOK dengan nilai ratarata sebesar $\mathrm{Rp}$ 8.370.000.000 dengan standar deviasi sebesar $\mathrm{Rp}$ 2.959.000.000.

\section{Hasil Analisis Regresi Linier Berganda}

Analisis ini digunakan untuk membuktikan ada atau tidaknya hubungan fungsional antara dua buah variabel bebas $(X)$ atau lebih dengan sebuah variabel terikat $(Y)$ dan mengetahui pengaruh dua atau lebih variabel predictor (variabel bebas) terhadap satu variabel kriterium (variabel terikat) atau untuk Usman dan Akbar (2006). Metode ini digunakan untuk menguji hipotesis adalah regresi linier berganda. Hal ini dimaksudkan untuk menguji komposisi PAD, DAU, DAK, dan DOK terhadap BM dengan melihat kekuatan hubungan antar BM dengan PAD, DAU, DAK, dan DOK.. Model regresi linier berganda tersebut adalah:

$$
\mathrm{Y}=\mathrm{a}+\mathrm{b} 1 \mathrm{X} 1+\mathrm{b} 2 \mathrm{X} 2+\mathrm{b} 3 \mathrm{X} 3+\mathrm{b} 4 \mathrm{X} 4+\mathrm{e}
$$

Keterangan :

$\mathrm{Y}=$ Belanja Modal 
a $\quad$ Konstanta

b1b2b3b4 = Koefisien Regresi untuk X1, X2, X3, dan X4

X1 $\quad=$ Pendapatan Asli Daerah (PAD)

X2 $=$ Dana Alokasi Umum (DAU)

X3 = Dana Alokasi Khusus (DAK)

X4 = Dana Otonomi Khusus (DOK)

e $\quad=$ Faktor lain ( Faktor Pengganggu)

Berikut ini adalah hasil uji analisis regresi linier berganda

Tabel 4.15

Hasil Analisis Regresi Linier Berganda

\begin{tabular}{|c|c|c|c|}
\hline Variabel & Coefficient & Uji t & Sig \\
\hline PAD_X1 & $-0,575$ & $-0,555$ & 0,595 \\
\hline DAU_X2 & 0,076 & 0,217 & 0,834 \\
\hline DAK_X3 & 0,945 & 0,877 & 0,406 \\
\hline DOK_X4 & 1,972 & 2,395 & 0,044 \\
\hline Constanta :-8.027 & & \\
\hline Uji $f: 3,805$ & & \\
\hline Sig $: 0,051$ & & \\
\hline R $: 0,655$ & & \\
\hline R $: 0,810$ & & \\
\hline N $: 13$ & & \\
\hline
\end{tabular}

Sumber: Hasil Output IBM SPSS 21, 2019 
Analisis regresi linear berganda digunakan untuk menguji seberapa kuat hubungan antara variable dependen dan variabel independen. Persamaan analisis linear berganda didapatkan sebagai berikut:

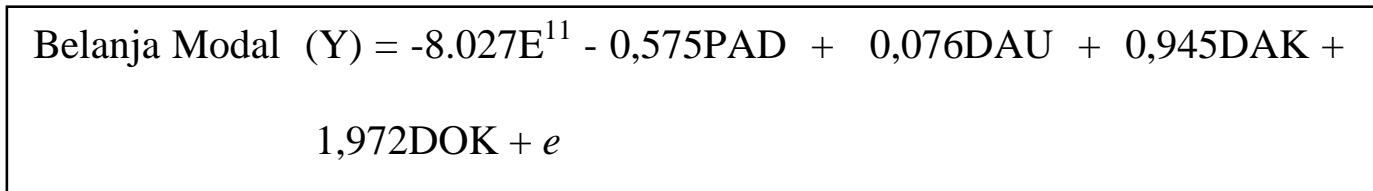

Hal ini membuktikan bahwa konstanta $\operatorname{sebesar}\left(-8.027^{\prime \prime}\right)$ dapat diartikan bahwa Y (Belanja Modal) akan bernilai $\left(-8.027^{11}\right)$ jika PAD, DAU, DAK dan DOK masing-masing bernilai 0 . PAD memiliki nilai sebesar $-0,575$, hal ini berarti apabila terjadi kenaikan PAD sebesar 1 juta rupiah maka akan terjadi penurunan belanja modal sebesar $-0,575$ juta rupiah atau dengan kata lain apabila PAD naik maka belanja modal akan turun.

Nilai DAU diketahui sebesar 0,076, artinya apabila terjadi kenaikan DAU sebesar 1 juta rupiah maka akan terjadi peningkatan belanja modal sejumlah 0,076 juta rupiah, dengan kata lain apabila DAU meningkat maka belanja modal juga akan naik.

Nilai DAK diketahui sebesar 0,945, artinya apabila terjadi kenaikan DAU sebesar 1 juta rupiah maka akan terjadi kenaikan belanja modal sebesar -0,296 juta rupiah, dengan kata lain apabila DAU naik maka belanja modal juga akan naik pula.

Nilai DOK diketahui sebesar 1,972, hal ini berarti apabila terjadi kenaikan DAK sebesar 1 juta rupiah maka akan terjadi kenaikan belanja modal sebesar 1,972, dengan kata lain apabila DOK naik maka belanja modal juga naik.

Nilai koefesian determinasi $\left(R^{2}\right)$ sebesar 0,655 yang mengandung arti bahwa variasi variabel PAD, DAU, DAK dan DOK dapat menjelaskan belanja modal di 
Provinsi Papua Barat sebesar 65,05\% sedangkan sisanya sebesar 40,06\% dijelaskan oleh variabel diluar model ini.

Menurut (Kuncoro, 2014), untuk mengurangi kesenjangan antara kebutuhan fiscal kapasitas daerah, maka Pemerintah Pusat memberikan Dana Alokasi Umum dalam bentuk block grant dan disebarkan dengan_formula berdasarkan prinsipprinsip tertentu yang secara umum mengidikasikan bahwa daerah tertinggal dan miskin harus menerima lebih banyak dari pada daerah kaya. Sedangkan menurut Menurut Mardiasmo (2004: 144), dalam pengalokasian DAU untuk mendukung penyelenggaraan pemerintah di daerah dan ketersediaan APBN demi mecapai tujuan pengalokasian DAU yakni menyeimbangankan keuangan antara pusat dan daerah harus memperhatikan kebutuhan pembiayaan potensi daerah.

Pengaruh PAD, DAU, DAK dan DOK Terhadap Belanja Modal di 12 Kabupaten 1 Kota di Provinsi Papua Barat, 2014-2018

Berdasarkan pengaruh dana alokasi umum, pendapatan asli daerah, dana otonomi khusus dan dana alokasi khusus terhadap belanja modal di Provinsi di 12 kabupaten 1 kota didapatkan hasil penelitian sebagai berikut :

\section{Pengaruh PAD Terhadap Belanja Modal}

Berdasarkan hasil analisis regresi diperoleh nilai signifikansi variable PAD adalah $0,595>0,05$. Artinya bahwa PAD tidak berpengaruh terhadap Belanja Modal di Papua Barat. PAD di Papua Barat dari tahun 2014-2018 terus mengalami peningkatan namun realisasi anggarannya kecil disebabkan oleh rendahnya retribusi daerah, pajak daerah, Lain-lain pendapatan asli daerah yang sah, pendapatan BUMD, sehingga menyebabkan pendapatan asli daerah (PAD) di Provinsi_Papua Barat rendah, ini merupakan fakta real yang terjadi di Provinsi Papua 
dan Papua Barat, yang mendapatkan peringkat terakhir di semua Provinsi yang ada di Indonesia, Oleh sebab itu diharapkan Pemerintah Daerah harus bisa mengembangkan sektor-sektor unggulan yang diharapkan dapat mendorong pendapatan daerah di Provinsi Papua Barat serta diharapkan kesadaran dari semua lapisan pemerintah, masyarakat dan pengusaha untuk dapat membayar pajak dan retribusi kepada pemerintah daerah.

Secara statistik Pendapatan Asli Daerah (PAD) tidak_berpengaruh terhadap belanja modal disebabkan, karena pendapatan asli daerah kecil sehingga tidak mampu untuk membiayai kebutuhan daerah. Besaran PAD yang dihasilkan oleh masing-masing daerah sangat bergantung kepada pajak daerah, retribusi daerah, badan usaha milik daerah dan lain-lain pendapatan yang sah keempat komponen ini yang sangat berpengaruh dan memberikan kontribusi terhadap PAD dan Pendapatan asli daerah dari setiap kabupaten/kota ataupun Provinsi berbedabeda.

Halim (2008: 96) semua penerimaan daerah yang bersumber dari ekonomi asli daerah merupakan Pendapatan Asli Daerah (PAD). Sementara menurut Darise (2008: 135), pendapatan yang diperoleh daerah yang dipungut berdasarkan peraturan daerah merupakan Pendapatan Asli Daerah (PAD). Dari kedua pengertian tersebut dapat disimpulkan bahwa yang dimaksud dengan Pendapatan Asli Daerah (PAD) adalah salah satu sumber yang menjadi pendapatan yang diterima daerah yang berasal potensi daerahnya masing-masing yang dapat di maksimalkan dan digunakan secara mandiri oleh daerah.

\section{Pengaruh DAU Terhadap_Belanja Modal}

Berdasarkan hasil analisis regresi diperoleh nilai signifikansi variable DAU adalah 0,834 >0,05. Artinya bahwa Dana Alokasi Umum (DAU) tidak berpengaruh 
terhadap Belanja Modal di Papua Barat. Namun realisasi anggaran setiap tahun terus mengalami peningkatan, sehingga seharusnya mampu mendorong pembangunan di bidang kesehatan, pendidikan, sarana-prasarana infrastruktur untuk mendorong percepatan pembangunan dan pemerataan antar pemerintah pusat dan daerah. Secara statistic dana aloaksi umum (DAU) tidak berpengaruh terhadap belanja modal. Sedangkan berdasarkan transfer pusat ke daerah Provinsi Papua Barat realisasi anggaran DAU yang tinggi pertama namun secara statistic tidak berpengaruh terhadap belanja modal, sehingga disimpulkan bahwa dana alokasi umum (DAU) belum terrealisasi dengan baik, untuk mendorong pembangunan di Papua Barat.

dalam rangka pelaksanaan desentralisasi (UU Nomor 33 Tahun 2004) pemerintah pusat mengalokasikan dana pembangunan yaitu DAU untuk mendanai kebutuhan daerah dengan tujuan pemerataan kemampuan euangan antar daerah. Untuk membiayai kekurangan dari pemerintah daerah, pemerintah pusat mengalokasikan Dana alokasi umum dalam memanfaatkan PAD daerah tersebut.

Menurut Kuncoro (2014: 63), mengurangi kesenjangan antara kapasitas dan kebutuhan fiskalnya, pemerintah pusat memeberikan Dana Alokasi Umum berupa block grant yang diberikan kepada kota dan kabupaten dengan maksud dan di distribusikan dengan formula berdasarkan prinsip-prinsip tertentu. Sedangkan menurut Menurut Mardiasmo (2004: 144), pembagian Dana Alokasi Umum perlu memperhatikan potensi daerah, kebutuhan pembiayaan untuk mendukung penyelenggaraan pemerintah di daerah dan ketersediaan APBN demi menjaga pemerataan dan perimbangan keuangan antara pusat dan daerah

\section{Pengaruh DAK Terhadap Belanja Modal}


Berdasarkan hasil analisis regresi diperoleh nilai signifikansi variable DAK adalah $0,406>0,05$. Artinya Dana Alokasi Khusus (DAK) tidak mempunyai pengaruh terhadap Belanja Modal di Papua Barat. Dana alokasi khusus (DAK) bersumber dari anggaran pemerintah belanja negara (APBN) yang didistribusikan dari pusat ke daerah di Papua Barat dari tahun 2014-2017 terus mengalami peningkatan realisasi anggarannya besar. Sehingga mampu mendorong pembangunan di bidang kesehatan, pendidikan, sarana-prasarana infrastruktur untuk mendorong percepatan pembangunan dan pemerataan antar pemerintah pusat dan daerah.

Dana alokasi khusus (DAK) adalah dana yang dialokasikan dari anggaran pendapatan belanja Negara (APBN) kepada Provinsi/Kabupaten/Kota dengan tujuan untuk membiayai kegiatan khusus yang merupakan urusan Pemerintahan Daerah sesuai dengan prioritas Nasional. Secara statistik dana Alokasi khusus (DAK) tidak berpengaruh terhadap belanja modal. Sedangkan berdasarkan transfer pusat ke daerah Provinsi Papua Barat realisasi anggaran DAK tertinggi ke-dua namun secara statistic tidak berpengaruh terhadap belanja modal, sehingga bisa disimpulkan bahwa dana alokasi khusus untuk membiayai kebutuhan aparatur sipil Negara (ASN) belum terrealisasi dengan baik, sehingga ASN di Papua Barat belum mampu bersaing dengan ASN yang ada di luar Papua, seperti penguasaan IPTEK dan Kinerja pegawai, di Papua Barat belum memadai.

Mardiasmo (2004; 144) menjelaskan bahwa Dana Alokasi Khusus (DAK) merupakan dana yang dialokasikan untuk membantu pembiayaan kebutuhan tertentu, yaitu merupakan program nasional atau program kegiatan yang tidak terdapat di daerah lain sedangkan menurut (Nurlan Darise, 2014: 137) untuk membiayai kebutuhan sarana dan prasara pelayanan dasar untuk 
masyarakat yang belum mencapai standar tertentu atau untuk mendorong percepat pembangunan daerah, diberikan Dana Alokasi Khusus yang berfungsi untuk membantu mendanai kegiatan-kegiatan khusus di daerah tertentu yang merupakan urusan daerah dan sesuai dengan prioritas nasional.

\section{Pengaruh DOK terhadap Belanja_Modal}

Berdasarkan hasil analisis regresi diperoleh nilai signifikansi variable PAD adalah $0,044<0,05$. Artinya bahwa Dana Otonomi Khusus (DOK) berpengaruh positif dan signifikan terhadap Belanja Modal di Papua Barat. Dana otonomi khusus (DOK) dialokasi untuk beberapa daerah yang diberikan otonomi khusus seperti daerah Aceh, Jogjakarta, Papua dan Papua Barat untuk membiayai kebutuhan-kebutuhan penting yang ada di daerah dan mendorong kesejahteraan masyarakat dan meningkatkan taraf hidup masyarakat di Provinsi Papua Barat. Secara statistik dana otonomi khusus (DOK) berpengaruh terhadap belanja modal, sedangkan berdasarkan transfer pusat ke daerah Provinsi Papua dan Papua Barat realisasi anggaran berdasarkan berdasarkan kebutuhan pembiayaan daerah, untuk Provinsi Papua mendapatan pengalokasian anggaran dana otonomi khusus (DOK) sebesar $80 \%$.

Karena memiliki 28 Kabupaten 1 Kota dan membutuhan pembiayaan yang besar, sedangkan provinsi Papua Barat mendapatan pengalokasian anggaran dana otonomi khusus (DOK) sebesar 30\% karena memiliki 12 Kabupaten 1 kota sehingga pembiayaan untuk kebutuhan daerah sedikit, namun secara statistik DOK berpengaruh terhadap belanja modal di Papua Barat, karena di Papua Barat untuk indeks pembangunan manusia (IPM) Papua Barat mendapatkan peringkat terakhir dari bawah di atas Provinsi Papua dari seluruh provinsi yang ada di indonesia. Dan sisi pertumbuhan ekonomi hampir disetiap Kabupaten/kota di Papua Barat merata. 
Besaran Dana otonomi khusus (DOK) berasal dari dana APBN disesuaikan kebutuhan dan alokasikan untuk Provinsi Aceh, Provinsi Papua, Provinsi Daerah Istimewa Yogyakarta dan Provinsi Papua Barat. Belanja modal mempunyai karakteristik spesifik yang menunjukkan adanya berbagai alasan sebagai bahan pertimbangan dalam pengalokasiannya. Alokasi belanja modal yang didasarkan pada kebutuhan mempunyai makna dimana tidak seluruh unit organisasi di pemerintahan daerah melaksanakan kegiatan atau proyek pengadaan aset tetap. Sesuai dengan tugas pokok dan fungsi (tupoksi) masing-masing satuan kerja yang memberikan pelayanan publik berupa penyediaan sarana dan prasarana fisik.

\section{Pengaruh PAD, DAU, DAK dan DOK Terhadap Belanja Modal}

Berdasarkan hasil penelitian DAK, PAD, DAU, secara bersama-sama tidak berpengaruh signifikan terhadap Belanja Modal di Papua Barat, karena Pendapatan Asli daerah yang bersumber dari ajak daerah, hasil pengelolaan kekayaan daerah yang di pisahkan, retribusi daerah, dan lain-lain masih sangat kecil penerimaanya bagi daerah sehingga tidak mempengaruhi belanja modal, selain itu Dana tersebut adalah dana yang bersumber dari pendapatan APBN yang didistribusikan dengan maksud pemerataan kemampuan keuangan antar Daerah yang difungsikan untuk mencukupi kebutuhan daerah dan di gunakan untuk belanja pegawai seperti gaji PNS daerah, sehingga DAU berpengaruh tidak signifikan terhadap Belanja Modal.

Dana Alokasi khusus (DAK) bertujuan untuk membantu membiayai kegiatan khusus yang merupakam urusan Daerah dan selaras dengan prioritas nasonal yang pertanggungjawaban langsung ke pusatdana tersebut bersumber dari pendapatan APBN yang di berikan kepada daerah tertentu dengan sehingga harus digunakan sesuai dengan aturan yang sudah ditetapkan dari pusat sehingga berpengaruh tetapi 
tidak signifikan. sedangkan Dana Otonomi Khusus (DOK) merupakan dana yang dialokasikan untuk membiayai pelaksanaan otonomi khusus di daerah, dimana penggunaannya juga sesuai kebutuhan daerah serta kewenangan sepenuhnya diatur oleh pemerinta daerah dalam perdasus dan berpengaruh signifikan terhadap belanja modal di Provinsi Papua Barat.

\section{KESIMPULAN}

Berdasarkan pembahasan dan hasil penelitian dengan judul "Pengaruh Pendapatan Asli Daerah, Dana Alokasi Umum, Dana Alokasi Khusus Terhadap Belanja Modal Di Provinsi Papua Barat Tahun 2014-2018", adapun kesimpulan sebagai berikut :

1. Belanja Modal di Provinsi Papua Barat tidak dipengaruhi oleh Pendapatan asli daerah (PAD), karena hasil dari PAD kecil, ini di sebab aset pemerintah daerah yang belum di kelola dengan baik,seperti pajak retribusi di beberapa daerah di Provinsi Papua Barat.

2. Belanja Modal pada 12 Kabupaten 1 kota di Provinsi Papua Barat tidak dipengaruhi oleh Dana alokasi umum (DAU) secara signifikan, karena DAU pengalokasiannya menekankan pada keteradilan yang selaras dan aspek pemerataan dengan urusan pemerintahan.

3. Dana otonomi khusus (DAK) berpengaruh tidak signifikan_terhadap Belanja Modal pada 12 kabupaten 1 kota di Provinsi Papua Barat, karena DAK merupakan dana yang bersumber dari APBN yang digunakan untuk mendanai kegiatan khusus seperti, pendidikan,kesehatan,infrastruktur, saranan prasarana dan ekonomi.

4. Dana otonomi khusus (DOK) memiliki pengaruh terhadap Belanja Modal pada 12 kabupaten 1 kota di Provinsi Papua Barat, karena Dana 
Otonomi Khusus diperuntukkan untuk memperkuat perdasus dan merupakan kewenangan daerah dan diatur sesuai dengan kebutuhan dan penggunaannya di perintah daerah di Provinsi Papua Barat.

5. Realisasi anggaran untuk belanja modal di 12 kabupaten 1 kota di provinsi papua barat tahun 2014-2018 yang bersumber dari PAD,DAU DAK dan DOK adalah sebesar Rp. 20.875.196.349.194,-

Berdasarkan hasil penelitian yang menggunakan model regresi linear berganda ini, diketahui bahwa dari keempat variabel yaitu Belanja modal tidak berpengaruh negative dan tidak secara signifikan olehDak, sedangkan DAU dan DAK berpengaruh tidak signifikan terhadap belanja modal sedangkan DOK sangat berpengaruh terhadap belanja modal di 12 Kabupaten 1 kota di Provinsi Papua Barat.

\section{DAFTAR PUSTAKA}

Arbie, W. (2013). Pengaruh PAD, DAU, DAK dan DBH Terhadap Belanja Modal. Jurnal Akuntansi.

Askam, T. (2008). Pengaruh DAU, DAK, PAD Dan PDRB Terhadap Belanja Modal Pemerintah Daerah Kabupaten/Kota Di Indonesia. Jurnal Telaah \& Riset Akuntansi, 1(2), 142-155.

Ayinde, K., Kuranga, J., \& Rukman, A. F. (2015). Modelling Nigerian Government Expenditure, Revenue and Economic Growth: Co-integration, Error Connection Merchanism and Combined Estimators Analysis Approach. Asian Economic and FInancial Review, 5(6), 858-867.

Barro, R. (1991). Government Spending in a Simple Model of Endogenous Growth. Journal of Political Economy.

Barro, R. J. (1998). Human Capital and Growth in Cross Country Regressions. Journal of Economics, (214).

Barro, R. S., \& Martin, S. I. (1995). Economic Growth. New York: McGraw Hill.

Buletin Teknis Sistem Akuntansi Pemerintah Nomor 4. Tentang Penyajian dan Pengungkapan Belanja Pemerintah.

Darise, N. (2008). Akuntansi Keuangan Daerah (Akuntansi Sektor Publik). Jakarta:Indeks.

Easterly, W., \& Rebelo, S. (1993). Fiscal Policy and Economic Growth: An Empirical Investigation. Journal of Monitery Economics, 32(3), 417-458.

Halim, A. (2008). Akuntasi Sektor Publik: Akuntansi Keuangan Daerah. Jakarta: Salemba Empat.

Halim, A. (2014). Manajemen Keuangan Sektor Publik: Problematika Penerimaan dan Pengeluaran Pemerintah. Jakarta: Salemba Empat. 
Harianto, D., \& Adi, P. H. (2007). Hubungan Antara Dana Alokasi Umum, Belanja Modal, Pendapatan Asli Daerah Dan Pendapatan Per Kapita. Simposium Nasional Akuntansi X, 26-28.

Kuncoro, S. (2014). Analisis Pengaruh Pertumbuhan Ekonomi, Tingkat Pengangguran, dan Pendidikan Terhadap Tingkat Kemiskinan Di Provinsi Jawa Timur 2009-2011. Universitas Muhammadiyah Surakarta.

Mardiasmo. (2002). Akuntansi Sektor Publik. Yogyakarta: Penerbit Andi.

Martini, N. L. D. S., Cipta, W., \& Suwendra, I. W. (2014). Pengaruh Pendapatan Asli Daerah, Dana Alokasi Umum dan Dana Alokasi Khusus Terhadap Belanja Modal Pada Kabupaten Buleleng Tahun 2006-2012. Jurnal Jurusan Manajemen, 2(1).

Mawarni, D., \& Abdullah, S. (2013). Pengaruh Pendapatan Asli Daerah dan Dana Alokasi Umum Terhadap Belanja Modal Serta Dampaknya Terhadap Pertumbuhan Ekonomi Daerah (Studi Pada Kabupaten/Kota di Aceh). Jurnal Akuntansi.

Peraturan Menteri Keuangan Nomor 145/PMK. 07/2013. Tentang Pengalokasian Anggaran Transfer Ke Daerah.

Verawaty, C. I. M., \& Mela, S. (2015). Determinan Pengalokasian Belanja Modal Dengan Pertumbuhan Ekonomi Sebagai Variabel Moderating Pada Pemerintah Provinsi Di Indonesia. Simposium Nasional Akuntansi XVIII.

Yovita, F. M. (2011). Pengaruh Pertumbuhan Ekonomi, Pendapatan Asli Daerah dan Dana Alokasi Umum Terhadap Pengalokasian Belanja Modal (Studi Empiris Pada Pemerintah Provinsi Se Indonesia Periode 2008-2010). Jurnal Akuntansi Fakultas Ekonomi Universitas Diponegoro. 